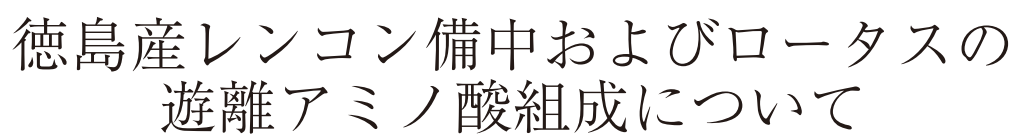

江戸 梢* ·橋本多美子** ·西尾幸郎 * · 沢田英司 $* * *$. 中川秀幸 $* * * *$

（*四国大学短期大学部, **武庫川女子大学生活環境学部,

***徳島県農林水産総合技術支援センター, ****四国大学看護学部)

(平成28年6月17日受付, 平成28年10月8日受理)

\title{
Free amino acid contents of roots of the lotus cultivars "Bicchu" and "Lotus" grown in Tokushima prefecture
}

\author{
Kozue Edo*, Tamiko Hashimoto**, Sachio Nishio*, \\ Eiji Sawada***, Hideyuki Nakagawa
}

* Junior College Division, Department of Science for Human Health, Shikoku University,

Furukawa, Ojin-cho, Tokushima-shi, Tokushima, 771-1192

** Department of Food Science and Nutrition, Mukogawa Women's University,

6-46, Ikebiraki-cho, Nishinomiya-shi, Hyogo, 633-8558

*** Tokushima Agriculture, Forestry, and Fisheries Technology Support Center, 1660, Ishii, Ishii-cho, Myohzai-gun, Tokushima, 779-3233

**** Department of Nursing, Shikoku University,

Furukawa, Ojin-cho, Tokushima-shi, Tokushima, 771-1192

$$
\begin{aligned}
& \text { * }=771-1192 \text { 徳島県徳島市応神町古川 } \\
& \text { ** } \text { \% 633-8558 兵庫県西宮市池開町 6-46 } \\
& \text { *** } 7779-3233 \text { 徳島県名西郡石井町石井字石井1660 } \\
& \text { ****7771-1192 徳島県徳島市応神町古川 }
\end{aligned}
$$

\footnotetext{
Tokushima prefecture is the second largest producer of lotus roots in Japan, with an annual harvest of approximately 8,000 tons. In the present study, we determined the contents of amino acids in the flesh, joint, and peel of lotus roots of two cultivars, "Bicchu" and "Lotus", grown in Tokushima prefecture. Asparagine, glutamine, arginine and alanine accounted for more than $60 \%$ of the total amino acids in the flesh of "Bicchu" and "Lotus" roots, while glutamine comprised around 5\% of the total amino acids in their joint and peel. When comparing the cultivars, "Lotus" roots contained the almost same level of $\gamma$-aminobutyric acid (GABA) than "Bicchu" roots, with a preferential distribution in the flesh. These results suggest the potential applications of the unused parts (joint and skin) of lotus roots grown in Tokushima prefecture as an ingredient in processed food products.
}

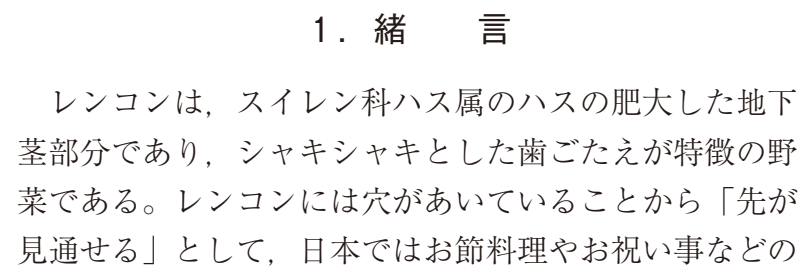

1. 緒言

レンコンは, スイレン科ハス属のハスの肥大した地下 茎部分であり, シャキシャキとした歯ごたえが特徴の野 菜である。レンコンには穴があいていることから「先が 見通せる」として，日本ではお節料理やお祝い事などの

慶事に欠かせない食べ物とされている ${ }^{11}$ 。徳島県は, レ ンコンの収穫量が年間約 8,000 トンにのぼっており, 全 国第 2 位の産地である。県内では露地栽培やハウス, 卜 ンネル栽培を組み合わせ，ほぼ一年を通してレンコンが 収穫されている2)。レンコンはビタミン C が豊富であり, 単位重量あたりミカンの 1.5 倍, 大根の 3.7 倍に相当する 
量が含まれている。また，でん粉が多いために加熱して もビタミン C の残存率が高い3) といわれて拉り，さら に野菜としては珍しくビタミン $\mathrm{B}_{12}$ も含まれている ${ }^{4)}$ 。 レンコンの機能性としては便秘解消, 貧血予防効果やコ レステロール低下作用などが知られている ${ }^{5,6}$ 。さらに 基礎的実験（動物実験）や臨床実験などが行われており， 抗酸化作用や比較的高いポリフェノール含量がみられ, 膵リパーゼ阻害活性や脂質代謝改善などの機能性食品と して有効であると報告されている ${ }^{7,8)}$ 。このように、レ ンコンは機能性食品素材の原料として活用することが期 待できる。一方, レンコンの収穫において, 可食部であっ ても収穫時に傷や污れが付いたもの, 根茎先端の $3 \sim 4$ 節以外のレンコン, 収穫時期の終盤に収穫されるものは, 通常よりも味や外観が劣る。消費者が見た目の良い商品 を好むこともあり，規格外のレンコンとして廃棄処分さ れることも多い9 ${ }^{9}$ 。

そこで本研究では, 徳島県産レンコン 2 品種の「備中」 および「ロータス」の可食部，節部㧍よび皮部を用いて アミノ酸生体液分析を行い，未利用資源である節部と皮 部の有効利用への可能性を検討することを目的とした。

\section{2. 実験方法}

\section{（1）実験試料}

レンコンは，徳島県産の「備中」拈よび「ロータス」 の 2 品種を使用した。各種レンコンを可食部・節部・皮 部に分け，ホモジナイザーにて磨砕したものを試料とし た（図 1 )。

\section{（2）分析方法}

遊離アミノ酸組成は，1品種につき可食部・節部・皮 部のそれぞれ $100 \mathrm{~g}$ を試料とし, 同量の $0.01 \mathrm{~N} \mathrm{HCL}$ 加え $100^{\circ} \mathrm{C}$ で20分間加熱を行い，遠心分離した後，限外 万過（15,000 rpm，20 min）後の分子量 10,000 以下の画 分を遊離アミノ酸分析試料とした。分析は日立 L-8800 型高速アミノ酸分析計を用い, アミノ酸生体液分析法で 行った。分析には各部位 1 サンプルを供し，分析した遊 離アミノ酸は $\gamma$ ーアミノ酪酸（GABA）を含む41種である。

\section{3. 結果および考察}

「備中」抢よび「ロータス」の 2 品種のレンコンに含 まれる遊離アミノ酸含量を部位別に比較した（表 1 ）。

「備中」 $100 \mathrm{~g}$ あたりの総アミノ酸量は, 可食部で $1,680.9 \mathrm{mg}$, 節部で $531.5 \mathrm{mg}$, 皮部で $1,493.8 \mathrm{mg}$ であっ た。

また「ロータス」では, $100 \mathrm{~g}$ あたりの総アミノ酸量 が可食部で $1,814.3 \mathrm{mg}$, 節部で $837.3 \mathrm{mg}$, 皮部で 1,750.1 mg であった。

鶴田ら ${ }^{6)}$ は，佐賀県産レンコンのアミノ酸含量ではア スパラギン酸が最も多く, 次いでグルタミン酸, セリン が多いと報告している。徳島県産の「備中」掠よび「ロー 夕久」と比較すると，アミノ酸含量に相異がみられた。 これは, レンコンの栽培された土壌や気温等の生育環境 の違い拈よび熱水抽出による分析法の違いによるものと 推察される。

また，アミノ酸には固有の味がある。代表的なものと して，甘味はグリシンやアラニン，苦味はバリンやロイ シン, 酸味およびうま味はグルタミン酸やアスパラギン 酸が挙げられる。「備中」では，甘味を示すグリシンお よびアラニンの含有率は可食部で $6.5 \%$, 節部で $6.2 \%$, 皮部で $2.0 \%$, 苦味を示すバリンおよびロイシンの含有 率は可食部で $5.5 \%$, 節部で $4.9 \%$, 皮部で $1.1 \%$ あった。 さらに，酸味㧤よびうま味を示すグルタミン酸およびア スパラギン酸の含有率は可食部で5. $4 \%$ ，節部で $6.3 \%$, 皮部で $3.3 \%$ であった。一方「ロータス」では，甘味を 示すグリシンおよびアラニンの含有率は可食部で $12.0 \%$, 節部で $12.2 \%$ ，皮部で $5.9 \%$ ，苦味を示すバリンおよび ロイシンの含有率は可食部で5.3\%, 節部で $3.6 \%$, 皮部 で1.7\%であった。酸味㧍よびうま味を示すグルタミン 酸捛よびアスパラギン酸の含有率は可食部で $4.2 \%$, 節 部で5.5\%，皮部で2.1\%であった。

総アミノ酸含量では可食部，皮部，節部の順に多く含 まれていた。「備中」では，可食部拉よび節部，皮部の いずれの部位に扔いても甘味および苦み，酸味，うま味 成分がバランスよく含まれており,「ロータス」は「備中」 に比べ甘味を示すアミノ酸が多く含まれていることが示
A

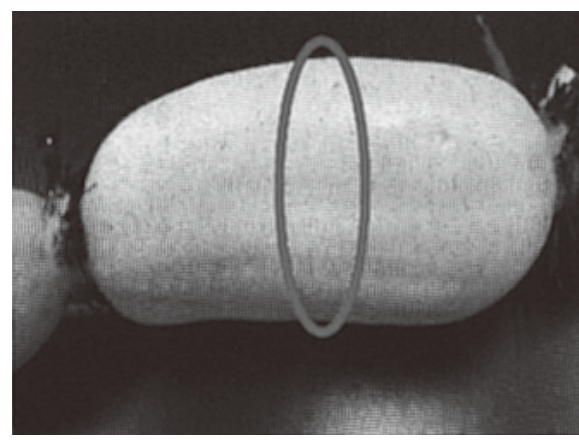

B

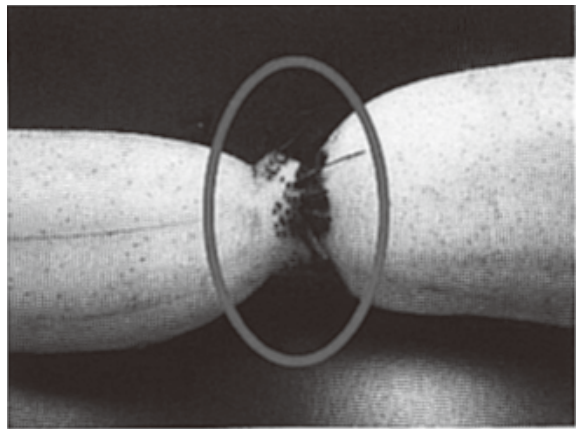

図 1 レンコンの可食部（A）と節部（B） 
徳島産レンコン備中およびロータスの遊離アミノ酸組成について

表 1 各レンコン品種における部位別の遊離アミノ酸含量

\begin{tabular}{|c|c|c|c|c|c|c|c|}
\hline \multirow{2}{*}{\multicolumn{2}{|c|}{$\begin{array}{c}\text { 遊離アミノ酸 } \\
(\mathrm{mg} / 100 \mathrm{~g})\end{array}$}} & \multicolumn{3}{|c|}{ 備 中 } & \multicolumn{3}{|c|}{ ロータス } \\
\hline & & 可食部 & 節部 & 皮部 & 可食部 & 節部 & 皮部 \\
\hline アルギニン & $(\operatorname{Arg})$ & 282.0 & 41.5 & 336.7 & 209.4 & 61.5 & 355.5 \\
\hline アラニン & (Ala) & 103.3 & 29.8 & 27.0 & 209.2 & 97.3 & 98.4 \\
\hline セリン & (Ser) & 60.9 & 15.1 & 17. 2 & 57.4 & 22.2 & 32.1 \\
\hline グルタミン酸 & (Glu) & 59.0 & 23.9 & 30.5 & 49.8 & 31.8 & 17.1 \\
\hline バリン & (Val) & 55.1 & 18.2 & 10.2 & 61.6 & 19. 4 & 18.7 \\
\hline チロシン & (Tyr) & 53.1 & 8.6 & 8.5 & 54.9 & 13. 1 & 18.6 \\
\hline トレオニン & (Thr) & 49.3 & 12.3 & 15.8 & 45.8 & 16.8 & 22.7 \\
\hline トリプトファン & $(\operatorname{Trp})$ & 48.1 & 3. 0 & 0.0 & 54.4 & 5.2 & 7. 1 \\
\hline ロイシン & (Leu) & 37.0 & 7. 6 & 5.8 & 34.6 & 10.5 & 11.1 \\
\hline アスパラギン酸 & (Asp) & 31.3 & 9.8 & 18.9 & 26.1 & 13.8 & 19.8 \\
\hline リジン & (Lys) & 28.3 & 5.9 & 21.2 & 30.8 & 10.2 & 25.1 \\
\hline メチオニン & (Met) & 25.4 & 0.9 & 6.4 & 31.3 & 5.7 & 8.2 \\
\hline ヒスチジン & (His) & 23.6 & 5.2 & 9.3 & 30.5 & 9.8 & 17.7 \\
\hline フェニルアラニン & (Phe) & 15.0 & 7. 0 & 5.9 & 19.8 & 8.8 & 7. 4 \\
\hline グリシン & (Gly) & 6.6 & 3.1 & 2.4 & 8.5 & 4.6 & 4.6 \\
\hline シスチン & (Cys) & 5.2 & 1.0 & 10.4 & 4. 2 & 1.4 & 10.7 \\
\hline プロリン & (Pro) & 0.0 & 0.0 & 0.0 & 0.0 & 0.0 & 0.0 \\
\hline イソロイシン & (Ile) & 0.0 & 11.1 & 8.1 & 40.4 & 13. 1 & 11.3 \\
\hline フォスフォセリン & (P-Ser) & 3.3 & 3. 1 & 4.3 & 2.6 & 5.7 & 4. 6 \\
\hline アスパラギン & $\left(\mathrm{AspNH}_{2}\right)$ & 476.7 & 150.1 & 825.8 & 476.5 & 313.4 & 862.1 \\
\hline グルタミン & $\left(\mathrm{GluNH}_{2}\right)$ & 200.6 & 20.7 & 62.8 & 284.1 & 74.6 & 92.3 \\
\hline$\gamma$ ノアミノ酪酸 & (GABA) & 60.8 & 34.9 & 46.4 & 60.3 & 49.8 & 60.7 \\
\hline シスタチオニン & (Cysthi) & 33.3 & 0.0 & 0.0 & 0.0 & 2.4 & 0.0 \\
\hline 1-メチルヒスチジン & (1Mehis) & 5.4 & 2.6 & 4.7 & 0.0 & 3.1 & 9.6 \\
\hline アンモニア & $\left(\mathrm{NH}_{3}\right)$ & 4.2 & 3. 2 & 3.5 & 4. 2 & 2.8 & 3.5 \\
\hline$\beta$-アラニン & (b-Ala) & 4.1 & 1.5 & 0.0 & 5.8 & 2.9 & 2.6 \\
\hline エタノールアミン & $\left(\mathrm{EOHNH}_{2}\right)$ & 3.1 & 2.9 & 3.5 & 4. 1 & 3.7 & 4.9 \\
\hline オルニチン & (Orn) & 2.1 & 0.8 & 1.2 & 2.6 & 1.1 & 2.4 \\
\hline ハイドロキシリジン & (Hylys) & 1.8 & 15.1 & 2.8 & 1.7 & 15.9 & 2.6 \\
\hline 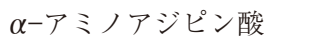 & (a-AAA) & 1.5 & 0.0 & 1.2 & 1.3 & 1.1 & 1.6 \\
\hline$\alpha$-アミノ- $n$-酪酸 & $(\mathrm{a}-\mathrm{ABA})$ & 0.5 & 0.0 & 0.0 & 1. 0 & 0.6 & 0.5 \\
\hline 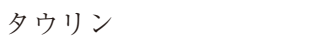 & (Tau) & 0.0 & 1.4 & 0.0 & 1. 0 & 0.7 & 0.0 \\
\hline ホスホエタノールアミン & (PEA) & 0.0 & 0.0 & 0.0 & 0.0 & 0.0 & 1.9 \\
\hline 尿素 ～～～～～～～ & (Urea) & 0.0 & 0.0 & 0.0 & 0.0 & 0.0 & 0.0 \\
\hline サルコシン & (Sar) & 0.0 & 0.0 & 0.0 & 0.0 & 0.0 & 0.0 \\
\hline シトルリン & (Cit) & 0.0 & 0.0 & 0.0 & 0.0 & 0.0 & 0.0 \\
\hline$\beta$-アミノイソ酪酸 & (b-AiBA) & 0.0 & 0.0 & 0.0 & 0.0 & 0.0 & 0.0 \\
\hline 3-メチルヒスチジン & (3Mehis) & 0.0 & 0.0 & 0.0 & 0.0 & 0.0 & 0.0 \\
\hline アンセリン & (Ans) & 0.0 & 0.0 & 0.0 & 0.0 & 0.0 & 0.0 \\
\hline カルノシン & (Car) & 0.0 & 12.7 & 3.5 & 0.0 & 14.2 & 14.6 \\
\hline Total & & $1,680.9$ & 531.5 & $1,493.8$ & $1,814.3$ & 837.3 & $1,750.1$ \\
\hline
\end{tabular}

唆された。

「備中」ではアスパラギン，アルギニン，グルタミン が多く，可食部に約60\%，節部に約40\%，皮部に約80\% を占めていた。一方，「ロータス」ではアスパラギン， グルタミン，アルギニン，アラニンが多く，可食部に約 65\%，節部に約65\%，皮部に約80\%を占めていた。

「備中」および「ロータス」の 2 品種のレンコン $100 \mathrm{~g}$ に含まれる GABA 含量を部位別に比較し, 図 2 に示した。

「備中」では可食部に $60.8 \mathrm{mg}(3.6 \%)$ ，節部に $34.9 \mathrm{mg}$ (6.6\%)，さらに皮部にも $46.4 \mathrm{mg}(3.1 \%)$ のABA が
含まれていた。また「ロータス」の可食部に $60.3 \mathrm{mg}$ (3.3\%), 節部に $49.8 \mathrm{mg}(6.0 \%)$, 皮部に60.7 mg (3.5\%) の GABA が含まれていた。「備中」および「ロータス」 の GABA 含量は可食部, 皮部, 節部の順に多く含まれ ていた。GABAは，健康機能性成分として注目されてい る。脳内では抑制性の神経伝達物質であると推定されて おり，ストレスの緩和や血圧の調整，脂質異常および動 脈硬化の抑制などの生活習慣病の改善にも有益であるこ とが報告されている ${ }^{10-13)}$ 。近年, 健康増進の観点から, 新たな食品加工技術によって食品中に含まれる GABA 


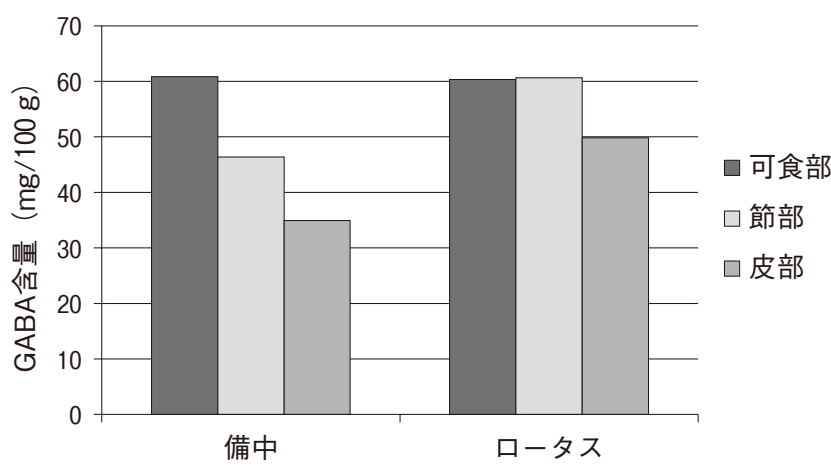

図 2 「備中」および「ロータス」における部位別の GABA 含量

含量を増強し，食品の高付加価值化を図ろうとする事例 も報告されている ${ }^{14,15)}$ Ｙuan ら ${ }^{16)}$ は、レンコン茶の製造 過程でグルタメートデカルボキシラーゼの活性の上昇に 応じて, GABA 含量を増加すると報告している。現在, GABA の関与する成分とする特定保健用食品は，血圧が

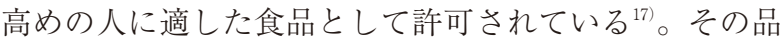
目では，概ね $100 \mathrm{~g}$ あたり $10 \mathrm{mg}$ 以上の GABA 含量が認 められる。今回の結果より，「備中」および「ロータス」 の可食部では $100 \mathrm{~g}$ あたり約 $60 \mathrm{mg}$ の $\mathrm{GABA}$ が含まれて おり，1日あたりレンコンを $20 \mathrm{~g}$ 程度摂取することで 特定保健用食品と同等の効果が期待されると考えられる。 レンコンは生の状態で可食部を調理により利用できるた けではなく，パウダーやペースト等に加工することで, 可食部に加えて皮部および節部も有効に活用することが できると考えられる。これまで廃棄されていた皮部拉よ び節部もレンコンパウダーやすりおろしてペースト状に する等の加工を行うことにより，パン類や菓子類をはじ めとする多様な食品に利用することが容易となり， GABA 富化による加工食品の高付加価值化を図るととも に未利用部分の有効利用の可能性が示唆された。

\section{文献}

1）農林水産省：農林水産省統計登録調査員通信, http:// www.maff.go.jp/j/tokei/kikaku/tyousain/pdf/sdayori_31.pdf

2 ）農林水産省中国四国農政局徳島地域センター：徳島の野 菜を食べましょう!，http://www.maff.go.jp/chushi/photo/ pdf/121029_36.pdf

3）農畜産業振興機構：今月の野菜 れんこん, http:// vegetable.alic.go.jp/yasaijoho/yasai/0702/yasai $1 . h t m l$

4）農畜産物振興機構：月報野菜情報今月の野菜, http://www.alic.go.jp/vegetable/

5 ）農林水産消費安全技術センター：新!! 大きな目小さな目, http://www.famic.go.jp/public_relations_magazine/ kouhoushi/back_number/201401-35.pdf
6）れんこん研究会：れんこん通信，Vol.010，http://renkon. or.jp/

7）鶴田裕美，柘植圭介，吉村臣史，江口良寿，小金丸和義 : 未利用資源の活用による食品素材の開発に関する研究—レ ンコンの in vitro に扔ける機能性評価について一，佐賀県工 業技術センター研究報告, 41-44（2006）

8）鶴田裕美，柘植圭介，吉村臣史，小金丸和義，柳田晃良， 永尾晃治：未利用資源の活用による食品素材の開発に関す る研究—レンコン粉末が肥満・糖尿病モデルマウスの脂質 代謝に及ぼす影響一, 佐賀県工業技術センター研究報告, $51-53(2007)$

9）れんこん研究会：れんこん通信，Vol.178，http://renkon. or.jp/

10）大森正司，矢野とし子，岡本順子，津志田藤二郎，村井 敏信, 樋口満：嫌気処理緑茶（ギャバロン茶）による高血 圧自然発症ラットの血圧上昇抑制作用, 日本農芸化学会誌, 61 (11) , 1449-1451 (1987)

11）水田時子，山田幸二：市販大豆もやしの生育過程におけ る $\gamma$ ーアミノ酪酸抢よび遊離アミノ酸組成の変動, 日本食生 活学会誌, 17 (4), 329-335（2006）

12）赤間一仁：GABA 強化米の開発, 日本農薬学会誌, 35 (2), 157-159 (2010)

13）池脇香織, 中村雅彦, 石附亨, 樋口元剛, 小川敬之, 山 田弘幸, 永井みどり, 小緑英行 : 米胚芽発酵ギャバ (GABA) エキス末入りパンの作製, 九州保健福祉大学研究紀要, 14, 149-155（2013）

14）茅原紘，杉浦友美：近年の GABA 生理機能研究一脳機能 改善作用，高血圧作用を中心に一，食品と開発，36（6）, 4-6 (2001)

15）安藤聡，森勝美，島純： $\gamma$-アミノ酪酸非資化性パン酵母 変異株の取得とその有用性, 日本食品科学工学会誌, 55 ( 1), 32-36 (2008)

16) Yuan, Xuecai, Ning, Changhong : One kind of lotus leafsemen cassia tea and its preparation method, Patent, CN 104798954 A 20150729 (2015)

17）消費者庁：特定保健用食品許可（承認）一覧，http:// www.caa.go.jp/foods/index4.html 